\title{
The Relation between Chemical Structure and Toxicity in Rotenone Derivatives
}

\author{
By Jun-ichi Fukami, Tsutomu Nakatsugawa and Toshio Narahashi \\ Division of Entomology, National institute of Agricultural Sciences, \\ Nishigahara, Tokyo, and Laboratory of Applied Entomology, \\ Faculty of Agriculture, University of Tokyo, Tokyo
}

The relationship between chemical structures of insecticides and their toxicities has been a subject of inquiry since development of synthetic insecticides such as DDT and parathion. Although some attempts have been made on this problem, no convincing conclusion was as yet obtained with any type of insecticide. Most of the attempts focused attention only to screening tests of insecticide derivatives for their insecticidal activities. However, since a number of processes are involved in the course of an insecticidal action, it seems likely that the insecticidal activity does not necessarily correlate with any particular radical or group in a molecule. In order to provide sufficient information concerning the relation between chemical structures and insecticidal activities, it is desirable to compare the effectiveness of derivatives at various steps in the course of an insecticidal action, e. g., penetration through the cuticle, detoxication in insect body, toxic effect at the site of action, and inhibition of enzymes.

Schrader (1947) and Metcalf \& March (1949) reported that insecticidal action of parathion and its derivatives closely correlated with the degree of cholinesterase inhibition. It has also been reported that DDT and its derivatives inhibit the cytochrome c oxidase activity (ANDERSON et al., 1954). In this case, however, since parallelism between insecticidal activities and the cytochrome $c$ oxidase inhibition was not found, the inhibition of this enzyme could not be regarded as a primary action of DDT.

Rotenone, which has a definite lethal action on insects and shows a low mammalian toxicity, has been demonstrated to inhibit L-glutamic dehydrogenase activity very effectively (FuKami, \& Tomizawa, 1956). The inhibition of this enzyme was considered to be responsible for block of nerve function which is a major cause of paralysis of insect after treatment with rotenone (FUKAMI, 1956; Fukami \& Tomizawa, 1956; Yamasaki \& Narahashi, 1957). It was further demonstrated with rotenone and its four derivatives that a close correlation exists between insecticidal action and the degree of $\mathrm{L}$ glutamic dehydrogenase from insect muscle (Fukami \& Tomizawa, 1958).

For the purpose of providing sufficient information on the relation between chemical structures of rotenoides and insecticidal activities, rotenone and thirtyfour derivatives were compared in the present study. For the reasons mentioned above, the effectiveness of derivatives in depressing L-glutamic dehydrogenase activity, in blocking nerve conduction, and in killing insects was examined.

The authors are indebted to Dr. $H$. IsHIKuRA, National Institute of Agricultural Sciences, for his ardent guidance, to Prof. T. YAMASAKI, University of Tokyo, and to Mr. C. Tomizawa, National Institute of Agricultural Sciences, for their valuable suggestions and criticisms. Thanks are also due to Prof. M. Matsur and Dr. M. Mryano, University of Tokyo, who kindly provided the rotenoides used in this

(Received for publication, June 18, 1959) 
experiment.

\section{MATERIALS AND METHODS}

Thirty-five rotenoides tested in this experiment were prepared by Prof. M. Matsui and Dr. M. Miyano, Laboratory of Organic Chemistry, Faculty of Agriculture, University of Tokyo. Among the compounds listed in Table 1 , those numbered $7,8,16,17,18,19,20,22,23,27,29,30,31$, $32,33,34$, and 35 are new compounds (Miyano \& Matsui, $1958 \mathrm{a} \sim \mathrm{g}$ ). All the compounds were used after purification and identification.

The azuki bean weevils, Callosburchus chinensis L., used for study were reared on the azuki bean at a constant temperature of $30^{\circ} \mathrm{C}$. The horned beetles, Xylotrupes dichotomus L., were collected in fields from July to August. They were fed on sucrose solution in the laboratory and used within 10 days after collection.

Insecticidal activities were evaluated as follows using the male adults of the azuki bean weevil within 24 hours after emergence. $1 \mathrm{ml}$ of acetone solution containing $20 \mathrm{r} / \mathrm{cm}^{2}$ of a test compound was spread uniformly on the bottom of a petri dish, $9 \mathrm{~cm}$ in diameter and $2 \mathrm{~cm}$ in height. After the solvent evaporated, 25 weevils were put into the petri dish and were kept in contact with the deposit of the test compound for 48 hours. They were then transferred on to a filter paper in another petri dish to determine the mortality. The experiments were carried out at a constant temperature of $28^{\circ} \mathrm{C}$.

The inhibition of L-glutamic dehydrogenase was measured manometrically with the mitochondrial fraction of muscles of the horned beetle. The mitochondrial fraction was prepared from the thoracic muscles of equal number of the male and female horned beetles by a slight modification of of the technique already reported (FukamI \& Tomizawa, 1956). $0.2 \mathrm{ml}$ of 10 per cent aqueous acetone solution containing a test compound was mixed in a Warburg vessel with $1.8 \mathrm{ml}$ of the mitochondrial suspension containing L-glutamate as substrate. The final concentration of test compounds was $10^{-5} \mathrm{M}$ and that of L-glutamate $10^{-2} \mathrm{M}$. After pre-incubation for 10 minutes, oxygen uptake was measured at $30^{\circ} \mathrm{C}$. Rotenone at $10^{-5} \mathrm{M}$ inhibited L-glutamic dehydrogenase by 50 to 70 per cent, and the degrees of inhibition by other compounds were expressed in percentages of the inhibitory degree of rotenone. Isolated abdominal nerve cords of the American cockroach, Periplaneta americana L., were used for examining the effects of rotenoids on conduction. A single electrical stimulus was applied to the end of the nerve cord through a pair of silver electrodes, while action potentials were recorded from the other end by another pair of silver electrodes. The action potentials recorded were observed by a C.R. amplifier and oscilloscope. Drug-acetone solution was suspended in Ringer's solution, and was applied to some $1 \mathrm{~mm}$ stretch of the central region of the nerve cord. The time necessary for the complete block of nerve conduction after treatment was taken as a measure of effectiveness of the test compound on nerve. The Ringer's solution used contained $214 \mathrm{mM} \mathrm{Na}{ }^{+}, 3.1$ $\mathrm{mM} \mathrm{K} \mathrm{K}^{+}, 1.8 \mathrm{mM} \mathrm{Ca}{ }^{++}$, and its $\mathrm{pH}$ was kept at $7.2 \sim 7.4$ by phosphate buffer.

\section{RESULTS AND DISCUSSION}

Examples of the changes in action potential of the nerve cord after treatment with test compounds are illustrated by Figs. 1 and 2. The chemical structures of rotenone and its derivatives tested are shown in Fig. 3. Summarized results are shown in Table 1. It will be seen that there is, as a whole, a close correlation between the three articles examined; any particular derivative which effectively inhibits the activity of L-glutamic dehydrogenase, blocks the nerve conduction quickly and possesses a high insecticidal activity. However, a few exceptions exist and will be discussed later.

It has been reported that the effectiveness of rotenone was due to the presence of chromano-chromanone - ring in the 


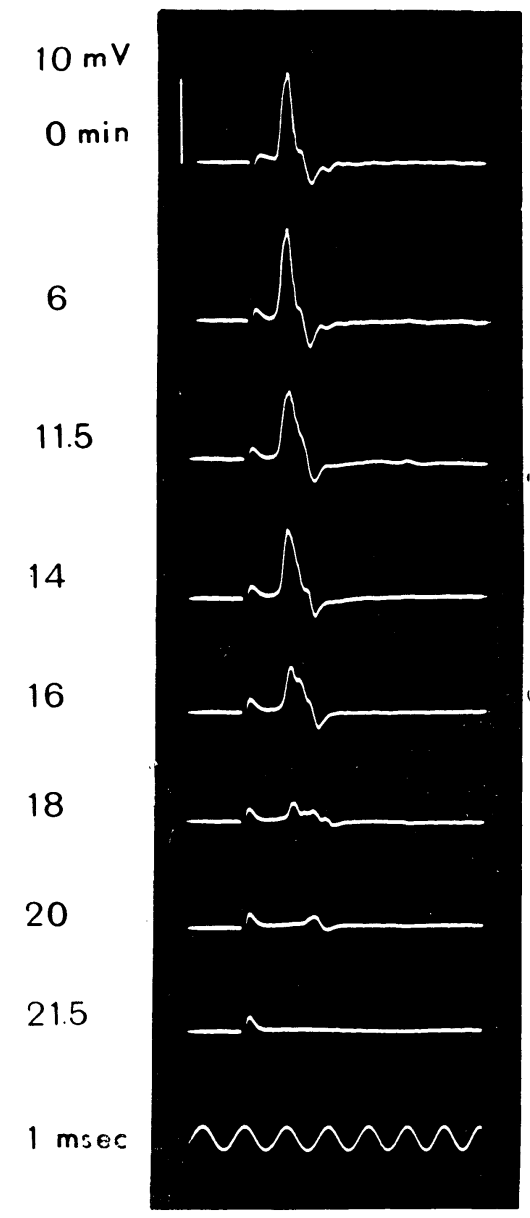

Fig. 1. Effect of $10^{-4} \mathrm{M}$ rotenone on the action potential of the cockroach nerve cord. Top record: Before treatment with rotenone. The other records: After treatment.

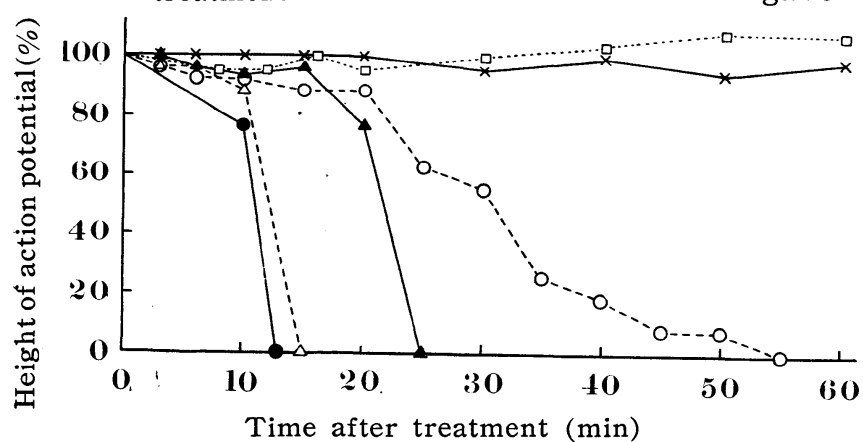

Fig. 2. Changes in the height of the action potential of the cockroach nerve after treatment with rotenone and its derivatives.

$\cdots \square \cdots$ : Control, $-\longrightarrow$ - $10^{-4} \mathrm{M}$ rotenone, $\cdots \triangle \cdots: 10^{-4} \mathrm{M}$ dihydro-rotenone, $-\Delta-$ : $10^{-4} \mathrm{M}$ rotenol,

..- -..: $10^{-4} \mathrm{M}$ iso-rotenone, $-\times-$ : $10^{-4} \mathrm{M}$ derrisic acid. molecule (DANN \& VALZ, 1954). The present experiments revealed, however, that acetyl-rotenone, rotenol and dihydrorotenol that have no chromano-chromanone ring had insecticidal activity. Rotenol stood to dihydro-rotenol as rotenone did to dihydro-rotenone both in structure and in toxicological behaviour. Considering the toxicities of rotenols, chromanochromanol ring seems as important as chromano-chromanone ring in rendering rotenoides toxic.

TAKEI (1958) and MARTIN (1946) reported that the asymmetric carbon atom at the position of 20 in the $\mathrm{E}$ ring (dihydro-furan ring) and two asymmetric carbon atoms at the position 7 and 8 in the central ring were very important to toxicity. Though dihydro-rotenone and rotenone-hydrochloride, having all three asymmetric carbons, showed both enzymic and nervous toxicities, the latter was not insecticidally effective. It seems probable that rotenonehydrochloride either could not penetrate the insect cuticle or was detoxified before reaching the site of action.

Iso-rotenone, degueline and tetrahydrorotenone, in all of which dihydro-furan ring of rotenone was altered, had either low or no toxicity probably due to the absence of asymmetric carbon atom at the position 20 .

Rotenolone-I, II and dehydro-rotenone gave evidence on the significance of hydrogen atoms on asymmetric carbons at the position 7 and 8 . Both rotenolone-I and II, which were produced by oxidation of either one of the asymmetric carbons of rotenone, had lower insecticidal activities. In addition, dehydro-rotenone which had neither of these two asymmetric carbons had no toxicity at all.

It had been assumed that the difference of structure between rotenolone-I and II was that of the position of $\mathrm{H}$ and $\mathrm{OH}$, and MARTin (1946) suggested that hydrogen atoms at the position 


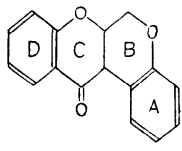

Chromano-chromanone ring

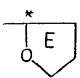

Dihydro-furan ring $\underbrace{0}_{0} \int^{*}$

Dihydro-pyronopyran ring

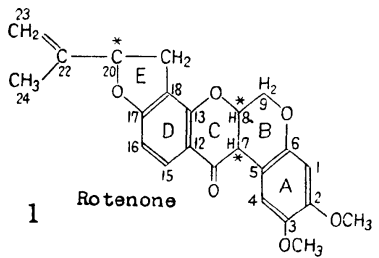

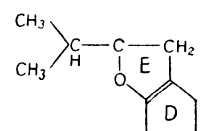

2

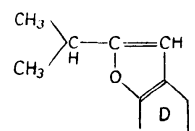

3<smiles>CC(C)(C)C1OC2CC3CCC(C2)C31</smiles>

4<smiles>CC1CCC(C)C2(C)CCCC12</smiles>

5<smiles>CCCCC(CC)=C(C)O</smiles><smiles>CC1=C(C)C(O)C(C)C(C)O1</smiles>

7

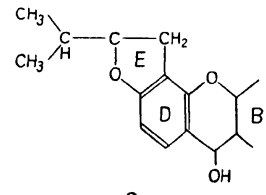

8<smiles>COC1C(C)=C(C)OC(C)C1C</smiles>

9

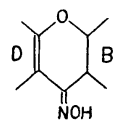

10

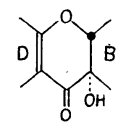

11

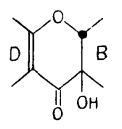

12

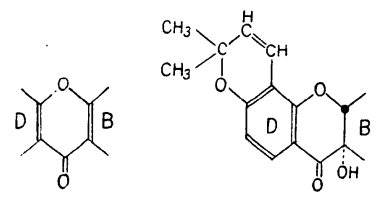

13

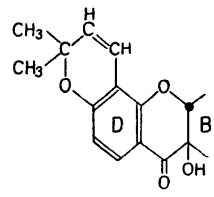

15<smiles>CC1=C(C)C(O)C(C)=[C+](C)O1</smiles>

16

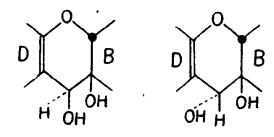

17

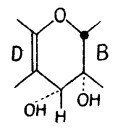

19

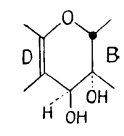

20

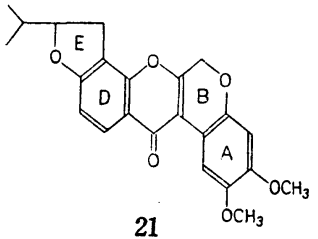

21

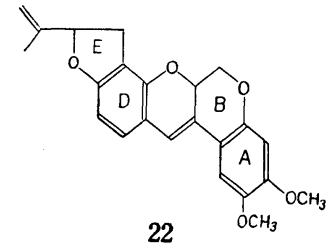

22<smiles></smiles>

26

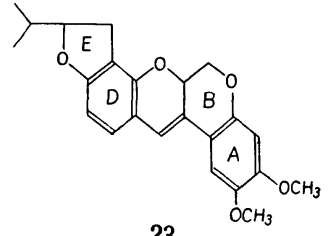

23
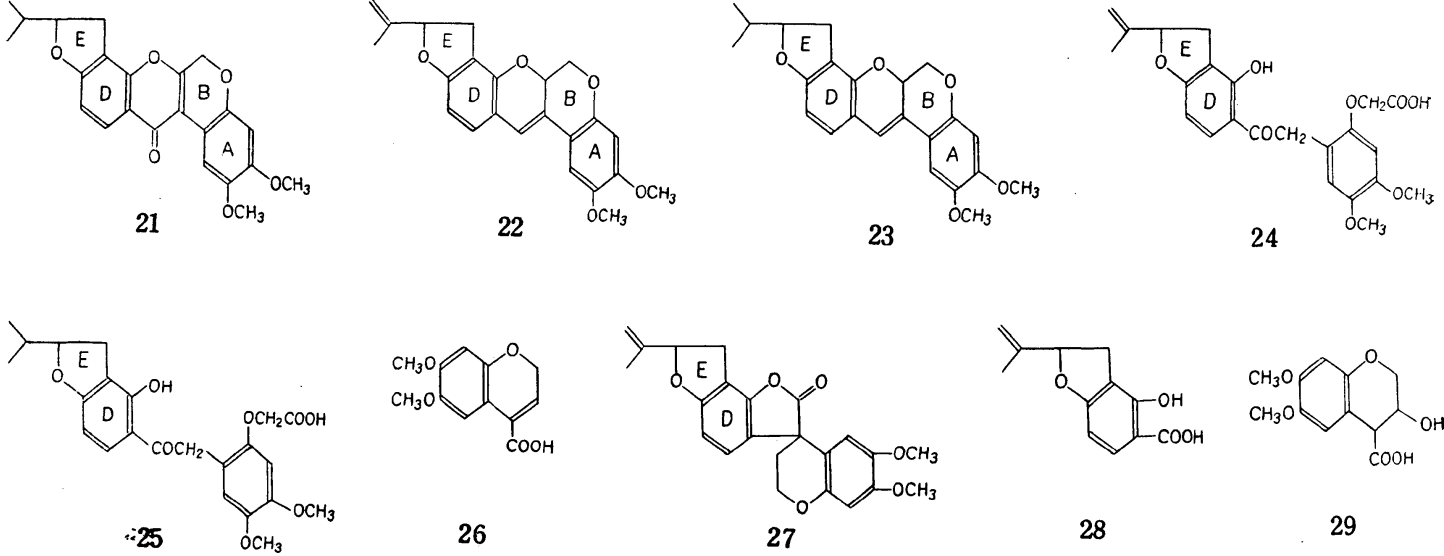

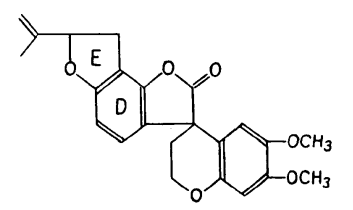

27

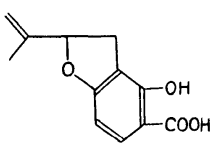

28

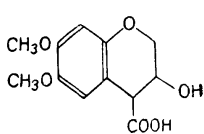

29

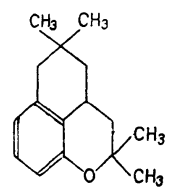

30

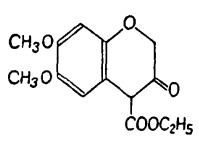

31<smiles>CC1(C)CC(=O)c2cc(O)c3c(c2O1)OC3</smiles>

32<smiles>C=C1C=Cc2ccccc2O1</smiles>

33

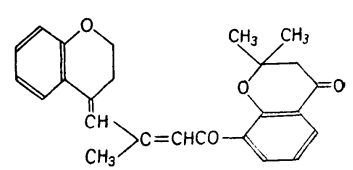

35

Fig. 3. Chemical structures of rotenone and its derivatives used 
Table 1. Inhibition of L-glutamic dehydrogenase, block of nerve conduction and insecticidal action by rotenone derivatives

\begin{tabular}{|c|c|c|c|c|c|c|c|c|}
\hline \multirow{4}{*}{ No } & \multirow{4}{*}{\multicolumn{2}{|c|}{$\begin{array}{c}\text { Insecticidal } \\
\text { toxicity }\end{array}$}} & \multirow{4}{*}{$\begin{array}{c}\text { Per cent } \\
\text { inhibition of } \\
\text { glutamic } \\
\text { dehydrogenase }\end{array}$} & \multirow{4}{*}{$\begin{array}{l}\text { Time for } \\
\text { block of } \\
\text { nerve } \\
\text { conduction } \\
\text { (min) } \\
\text { (No. of } \\
\text { preparation) }\end{array}$} & \multirow{4}{*}{$\begin{array}{l}\text { Chromano- } \\
\text { chromanone } \\
\text { ring }\end{array}$} & \multicolumn{2}{|c|}{ Chemical structure } & \\
\hline & & & & & & \multicolumn{3}{|c|}{$\begin{array}{l}\text { Asymmetric carbon } \\
\text { atom (s) in }\end{array}$} \\
\hline & & & & & & \multirow{2}{*}{$\begin{array}{l}\text { Didydro- } \\
\text { furan ring }\end{array}$} & \multicolumn{2}{|c|}{$\begin{array}{c}\text { Dihydro-pyron- } \\
\text { pyran ring }\end{array}$} \\
\hline & & & & & & & $\underset{7}{\text { Position }}$ & $\begin{array}{l}\text { Position } \\
8\end{array}$ \\
\hline 1. & Rotenone & 100 & $95 \sim 100$ & $17(15)$ & + & + & + & + \\
\hline 2. & Dihydro-rotenone & 75 & $92 \sim 100$ & $18(6)$ & + & + & + & + \\
\hline 3. & Iso-rotenone & 0 & $21.5 \sim 22.5$ & $40(2),>80(4)$ & + & - & + & + \\
\hline 4. & Rotenone-hydrochloride & 20 & $89 \sim 100$ & $23(5),>60(1)$ & + & + & + & + \\
\hline 5. & Degueline & 60 & $68 \sim 73$ & $45(6)$ & + & - & + & + \\
\hline 6. & Tetrahydro-rotenone & 0 & 0 & & + & - & + & + \\
\hline 7. & Rotenol (N) & 50 & $75 \sim 84.5$ & $26(6)$ & - & + & + & $F$ \\
\hline 8. & Dihydro-rotenol $(\mathrm{N})$ & $0 \sim 35$ & $68 \sim 85$ & $47(5),>80(1)$ & - & + & + & + \\
\hline 9. & Acetyl-rotenone & 50 & $70 \sim 74$ & $25(6)$ & - & + & + & + \\
\hline 10. & Rotenone-oxim & 0 & 15.5 & & - & + & + & + \\
\hline 11. & Rotenolone-I & $0 \sim 30$ & $45 \sim 56$ & $16(6)$ & \pm & + & + & + \\
\hline 12. & Rotenolone-II & 0 & $0 \sim 9.0$ & $33(3),>60(6)$ & \pm & + & + & + \\
\hline 13. & Dehydro-rotenone & 0 & 3.5 & $>60(6)$ & - & + & - & - \\
\hline 14. & Deguelinol-I & 0 & 0 & & \pm & - & + & + \\
\hline 15. & Deguelinol-II & 0 & 0 & & \pm & - & + & + \\
\hline & Dehydro-rotenol (N) & 0 & 8.0 & & - & + & - & - \\
\hline 17. & Rotenolol-II $\alpha(\mathrm{N})$ & 0 & 0 & & - & + & + & + \\
\hline & Rotenolol-II $\beta$ (N) & 0 & 0 & & - & + & + & + \\
\hline 19. & Rotenolol-I $\alpha(\mathrm{N})$ & 0 & 0 & & - & + & + & + \\
\hline 20. & Rotenolol-I $\beta$ (N) & 0 & 0 & & - & + & + & + \\
\hline & $\begin{array}{l}\text { Dihydrodehydro- } \\
\text { rotenone }\end{array}$ & 0 & 0 & & - & + & - & - \\
\hline & $\begin{array}{l}\text { Desoxy-dehydro- } \\
\text { rotenone }(\mathrm{N})\end{array}$ & 0 & 2.5 & & - & + & - & + \\
\hline & $\begin{array}{l}\text { Dihydro-desoxy-dehydro- } \\
\text { rotenone }(\mathrm{N})\end{array}$ & 0 & 13.0 & & - & + & - & + \\
\hline & Derrisic acid & 0 & 0 & $>60(6)$ & - & + & - & - \\
\hline & Dihydro-derrisic acid & 0 & 0 & $>60(6)$ & - & + & - & - \\
\hline & Toxicaric acid & 0 & $7.5 \sim 10.5$ & $>60(6)$ & - & - & - & - \\
\hline & $(\mathrm{N})$ & 0 & 0 & & - & + & - & - \\
\hline & Tubaic acid & 0 & 0 & & - & + & - & - \\
\hline 29. & $(\mathrm{~N})$ & 0 & 0 & & - & - & - & - \\
\hline 30. & $(\mathrm{~N})$ & 0 & 0 & & - & - & - & - \\
\hline 31. & $(\mathrm{~N})$ & 0 & 0 & & - & - & - & - \\
\hline 32. & $(\mathrm{~N})$ & 0 & 0 & & - & - & - & - \\
\hline 33. & (N) & 0 & 4.5 & & & & & \\
\hline & $\begin{array}{l}\mathrm{C}_{23} \mathrm{H}_{22} \mathrm{O}_{6}(\mathrm{~N}) \\
\text { (Isomer of rotenone) }\end{array}$ & 0 & 0 & & - & - & - & - \\
\hline 35. & (N) & 0 & 0 & & - & - & - & - \\
\hline
\end{tabular}

N: New compound.

of 7 and 8 were important in determining the toxicity of rotenoides.

According to recent studies, however, the difference lies in stereoconfiguration of the two rotenolones, rotenolone-I having trans- and rotenolone-II cis-configurations (Miyano \& Matsui, 1958f). The present results on the two compounds showed that trans-configuration at the position of 7 and 8 was more important than cis- configuration there.

Compound 32, a derivative of chromanone, had no toxicity, although DANN \& VALZ (1954)reported some toxic chromanone derivatives.

It is concluded that in the case of rotenoides, a close correlation exists between the inhibition of L-glutamic dehydrogenase, the block of nerve conduction, and the insecticidal activity. In no 
case is there high insecticidal activity in the absence of enzyme inhibition. These results confirm the previous conclusion that the inhibition of L-glutamic dehydrogenase plays a major part in killing insects.

\section{SUMMARY}

Rotenone and its thirty-four derivatives including seventeen new compounds have been examined for their insecticidal toxicities, enzymic inhibition and nervous toxicities, using the azuki bean weevil, the thoracic muscle mitochondria of the horned beetle and the nerve cord of the American cockroach, respectively.

A close correlation existed between in vitro inhibition of glutamic dehydrogenase system, block of nerve conduction and insecticidal activity.

The relation of the chemical structures of rotenone derivatives to their toxicities was discussed. Though it has been reported that the effectiveness of rotenoides is due to the presence of chromanochromanone ring in the molecule, the present results show that chromanochromanol ring is also as important.

Trans-configuration at the position 7 and 8 was more toxic than cis-configuration there.

\section{LITERATURES}

Anderson, A. D., R. B. March \& R. L. Metcalf (1954) Ann. Ent. Soc. Amer. 47: 595.
DAnN, von O. \& G. VALz (1954) Huber D. Ann. 587: $16 *$.

Fukami, J. (1956) Botyu-Kagaku 21: 122.

Fukami, J. \& C. Tomizawa (1956) Botyu-Kagaku 21: 128.

Fukami, J. \& C. Tomizawa (1958) Botyu-Kagaku 23: 1.

Martin, H. (1946) J. Soc. Chem. Ind., London 65: 402.

Metcalf, R. L. \& R. B. March (1949) J. Econ. Ent. 42: 721.

Miyano, M. \& M. Matsui (1958a) Bull. Chem. Soc. Japan 31: 268.

Miyano, M. \& M. Matsui (1958b) Bull. Chem. Soc. Japan 31: 271.

Miyano, M. \& M. Matsui (1958c) Bull. Chem. Soc. Japan 31: 397.

Miyano, M. \& M. Matsui (1958d) Chem. Ber. 10: 2044.

Miyano, M. \& M. Matsui (1958e) Bull. Agr. Chem. Soc. Japan 22: 128.

Miyano, M. \& M. Matsui (1958f) Bull. Agr. Chem. Soc. Japan 22: 335.

Miyano, M. \& M. Matsui (1958g) Bull. Agr. Chem. Soc. Japan 22: 337.

TAKEI, S. (1958) Seibutsukagaku Saikin No Shinpo 4: 240.

SchRADER, G. (1947) British Intelligence. Objectives Subcommittee Final Report 714 (revised). Item No. 8. London-H. M. Stationery Office*.

Yamasaki, T. \& T. Narahashi (1957) BotyuKagaku 22: 354.

Note: Papers marked with asterisk were referred to indirectly.

\section{摘 \\ 要 \\ ロテノン誘導体の化学構造と薬理作用 \\ 媣見順一・中津川勉・楢橋 敏 夫}

農林省農業技術研究所病理昆虫部 - 東京大学農学部害虫学研究室

ロテノン江戦後現われた有機合成殺虫剂と違って人畜 に対し低毒性で，また植物に対する薬害も少ない優秀な 天然殺虫剤の一つである。すでに筆者らは，ロテノンは こえ虫体内で神経および筋肉の細胞呼吸を抑制し, 死に
至らしめるが，その細胞呼吸抑制の一部は L-グルタミ ン酸脱水素䣼素系の抑制によるものであると結論した (深見・富沢, 1956)。さて今回はロテノンの化学構造と 殺虫力との関係を知るために, こん虫筋肉 L-グルタ 
ン酸脱水素酵素阻害力, 殺虫力およびこん虫神経の興奮 伝導抑制力定，ロテノンおよび 34 種のロテノン誘導体 について比較検討した。

こん虫L-グルタミン酸脱水素酵素としては, カブトム シ筋肉のミトコンドリアを材料として，グルタミン酸添 加時の酸素吸収量を測定した。殺虫試験としてはアズキ ゾウムシを使用し，常法によって実験を行なった。また こん虫神経の興奮伝導は，ワモンゴキブリ腹部神経索の 単一刺激による活動電位を, オシログラフを用いて測定 した。使用したロテノン誘導体は東大農学部有機化学教 室より供与されたものである。そのうち 17 はすでに化 学構造が明らかにされていたが, 残り 17 は新しく作ら れたものである。
これらについて酵素阻害力, 興奮伝導抑制力および殺 虫力の間に明らかな平行関係がみられた。殺虫力と酵素 阻害力乞の関係については, METCALF \& MARCH (1949) が有機リン殺虫冎のコリンエステラーゼ阻害力と殺虫力 との間の平行関係を見いだして以来, 他の殺虫郕では初 めてである。また化学構造と殺虫力との関係について は, 従来密接な関係があるといわれていた chromanochromanone 核は必ずしも必須条件ではなく, chromano-chromanol 核も有望である。さらに 11 位がア セチル化されたアセチルロテノンも殺虫性があった。ロ テノンの殺虫性においては，また7位および8位におけ るトランス構造のほうがシス構造よりも重要であった。
抄

\section{カミキリムシ幼虫の栄養生理 I}

Rasmussen, S. (1956) Nutritional preference experiments with larvae of house longhorn beetle, Hylotrupes bajulus. Oikos (Acta Oecologica Scandinavica) $7: 82 \sim 97$.

カミキリムシの一種 Hylotrupes bajulus は松材を食 べるが，その表㬝に近い部分だけをせん（穿）孔し，心 部には食入しない。ての原因の一つとして, 本種が材中 のペプトン含量の相違を選択できるか不かを，特殊な人 工食餌で調べた。

人工食餌は松の白木で造った薄板またはろ(沪)紙で， これに種々の濃度 $(0,1,2,4,8 \%)$ のペプトン水溶液 をしみこませ，その何枚かを 2 枚のガラス板の間にはさ んで「合板」としたものである。合板は選択実験の場合 にはペナトンの薄いものから濃いものへと順に合わせ， 中央の板(またはろ紙)にきりで穴をあけてふ化したての 幼虫を入れた。また, 実験の半分はイース卜の水抽出物 を加光た。ての合板を $89 \%$ R. H., $27^{\circ} \mathrm{C}$ 飞保存し, 3 カ月後に開いて幼虫の成長状態打上び栄養選択を調べ た。幼虫の体重は, 木材の場合もろ紙の場合も, ペプト ンの多い区ほぞ重く, 特に木材にイーストを加えた区で はペプトンの添加によって著しい增加がみられた。栄 養選択の実験では，万紙の場合も木材の場合も，（1） 大部分の幼虫はペプトン量の多い首に食入していたこ と，（2）ペプトン量の多い周に食入した個体のほうが 大きかったととがわかった（しかし，どの実験でも 1 割 前後がペプトンの少ないほうへ食入している。すちろん 接種時の幼虫の頭部は半分はパプトンの少ないほうへ,

\section{録}

他の半分は多いほうへ向けて扔いた)。死亡率は木材で 約 6\%，万紙で約 $25 \%$ であって, ペプトン濃度とは無 関係であった。かくて，本種の幼虫は，せん孔中にぺプ トン濃度の異なった材を選好し，またこの行動は栄養的 役割を果たしている。

（農技研 伊藤嘉昭）

\section{カミキリムシの栄䓹生理 II}

RASmussen, S. (1956) On the significance of cholesterol and yeast extract in the diet of larvae of house longhorn beetle (Hylotrupes bajulus). Oikos (Acta Oecologica Scandinavica) $7: 243 \sim$ 250.

前報で述べたろ紙合板法によってカそキリムシの一種 Hylotrupes bajulus の栄養要求を調べた。ろ紙に一ぺ プトンとイーストの水抽出物を加えて本種の㭃虫を飼育 すると，その成長はペプトンが多いはど良く，またイ一 スト抽出物がはいっているほうが良いが，最良の場合で す完全に成熟せず，木材の場合より小さい発育段陼で止 まる。これに人工飼料 $1 \mathrm{~g}$ あたり $0.15 \mathrm{mg}$ のコレステ ロールを加えると, 上記の栄養欠乏の様子はなくなる。 結局，ペプトンは幼虫がどのくらい大きくなれるかとい うととに関係し，イーストから抽出されたビタミンとコ レステロールとは，うっと質的な要因として働らいてい るようである。イーストを加えなくてもある程度成長す るととは，ペプトン中に含まれる $\mathrm{B}_{1}$ と $\mathrm{B}_{2}$ (ペプトン $1 \mathrm{~g}$ あたり $\mathrm{B}_{1} 3.0 \mu \mathrm{g} ， \mathrm{~B}_{2} 5.0 \mu \mathrm{g}$ )によるのであろう。

（農技研 伊藤嘉昭） 